\title{
Diagnostic Utility of Biomarkers in COPD
}

\author{
Vivek N Ambade MSc, Alka N Sontakke MD, MS Barthwal MD DM, R Tyagi MD, and \\ Dashrath R Basannar MSc
}

\begin{abstract}
BACKGROUND: COPD will become the third leading cause of death by 2020. There are many situations in which spirometry, the primary tool for diagnosis of COPD, cannot be performed, and thus, the staging and status of these patients cannot be determined. To date, there is no known biochemical marker used for diagnosing COPD. This study aimed to explore the utility of biomarkers for diagnosis of COPD. METHODS: This was an observational study composed of 96 stable subjects with COPD and 96 subjects with normal lung function. Each group contained an equal number of smokers and nonsmokers. Serum levels of superoxide dismutase 3, glutathione peroxidase, catalase, ceruloplasmin ferroxidase activity, C-reactive protein, and surfactant protein D (SPD) were estimated. Ferroxidase activity was estimated by a kinetic method, whereas the other analytes were measured by enzyme-linked immunosorbent assay. The cutoff value, sensitivity and specificity at the cutoff value, and area under the curve for each analyte were determined from receiver operating characteristic curve. RESULTS: Significantly decreased superoxide dismutase 3 and increased ferroxidase activity, SPD, glutathione peroxidase, and C-reactive protein levels were found in subjects with COPD. For all subjects and nonsmoking subjects with COPD, the area under the curve was highest for ferroxidase activity, followed by glutathione peroxidase, SPD, and C-reactive protein, with a sensitivity and specificity of $>73 \%$. For smoking subjects with COPD, the area under the curve was highest for SPD, followed by glutathione peroxidase, ferroxidase activity, and $\mathrm{C}$-reactive protein, with a sensitivity and specificity $>67 \%$. Some combinations of markers were found to give either a sensitivity or specificity of $>95 \%$, which can be utilized to rule in and rule out COPD. CONCLUSIONS: Biomarkers can be reliably utilized in the diagnosis of COPD. Of all the markers, SPD appears to be the most promising in smokers, whereas ferroxidase activity shows promise in nonsmokers. To rule out COPD, ferroxidase activity or glutathione peroxidase can be potentially useful, whereas to rule in COPD, ferroxidase activity and glutathione peroxidase appear to be the most promising combination in both nonsmoking and smoking subjects. Key words: chronic obstructive pulmonary disease; antioxidants; surfactant protein D; ceruloplasmin ferroxidase; superoxide dismutase 3; catalase; C-reactive protein; glutathione peroxidase; biomarker. [Respir Care 2015;60(12):1729-1742. (c) 2015 Daedalus Enterprises]
\end{abstract}

\section{Introduction}

The World Health Organization projects that COPD will rank fifth in 2020 in disease burden worldwide. ${ }^{1}$ The Global

\footnotetext{
Mr Ambade is affiliated with the Department of Biochemistry, and $\mathrm{Mr}$ Basannar is affiliated with the Department of Community Medicine, Armed Forces Medical College, Pune, India. Dr Sontakke is affiliated with the Department of Biochemistry, Maharashtra Institute of Medical Education and Research Medical College, Talegaon, Pune, India. Drs Barthwal and Tyagi are affiliated with the Department of Respiratory Medicine, Cardio-Thoracic Centre, Pune, India.
}

Burden of Disease Study projected that COPD will be the third leading cause of death globally by $2020,{ }^{2}$ whereas a more recent projection estimated that COPD will be the fourth leading cause of death in $2030 .{ }^{3}$ Yet COPD remains relatively unknown or ignored both by the public and some government officials and remains a major public health problem.

\footnotetext{
This study was supported by the Defence Research and Development Organisation. The authors have disclosed no conflicts of interest.
} 
The American Thoracic Society (ATS) and the European Respiratory Society (ERS), ${ }^{4,5}$ along with the Global Initiative for Chronic Obstructive Lung Disease (GOLD), ${ }^{6,7}$ recommend spirometry $\left(\mathrm{FEV}_{1} / \mathrm{FVC}<0.70\right)$ for the diagnosis of COPD. This age-based spirometry criterion has been reported to substantially over- or underdiagnose COPD. ${ }^{8}$ Spirometry-based COPD prevalence estimates differ extensively based upon the criteria used to diagnose COPD. ${ }^{9,10}$ Moreover, the validity of spirometry findings and their utility in the management of patients with COPD to date are unclear and questionable. ${ }^{11-15}$ Moreover, spirometry cannot be performed on all patients. Haynes ${ }^{16}$ reported the inability of subjects to exhale for $\geq 6 \mathrm{~s}$ as the most common reason, whereas Hardie et $\mathrm{al}^{17}$ reported a variety of other reasons for spirometry failure. The inherent problems associated with spirometry warrant the need for biomarkers. Until now, no serum biomarker has been reported for use in diagnosing COPD. Continuous lung exposure to exogenous and endogenous oxidants necessitated an efficient, well-developed antioxidant mechanism consisting of enzymatic antioxidants such as superoxide dismutase, glutathione peroxidase, glutathione reductase, catalase, and ceruloplasmin ferroxidase activity and various non-enzymatic antioxidants. ${ }^{18-21}$ Normally, a balance exists, but increased pulmonary exposure to oxidative sources and/or reduced antioxidant defenses leads to oxidative stress, which has been implicated in the pathogenesis of COPD. ${ }^{22}$ Decreased endogenous antioxidants due to reduced levels of nuclear factor erythroid 2-related factor 2 , which regulates several antioxidant genes, have been reported in subjects with COPD, resulting in increased oxidative stress, leading to COPD. ${ }^{23}$ Thus, estimation of antioxidant markers may help in the diagnosis of COPD.

Promising biomarkers that have received the most recent attention are C-reactive protein and fibrinogen. ${ }^{24-26} \mathrm{~A}$ new biomarker, surfactant protein D (SPD), the serum levels of which are elevated in response to lung pathology, has been suggested as a useful lung-specific marker of COPD. ${ }^{27}$ As the search for COPD biomarkers continues ${ }^{28}$ and implementation of biomarkers for COPD in actual clinical practice requires much research and validation, ${ }^{29}$ this study aimed to explore the utility of levels of superoxide dismutase 3, glutathione peroxidase, catalase, and ceruloplasmin ferroxidase activity (enzyme antioxidants); C-reactive protein (inflammatory marker); and SPD (lungspecific protein) as biomarkers for diagnosis of COPD.

Correspondence: Vivek N Ambade MSc. E-mail: vivekambade@ rediffmail.com.

DOI: $10.4187 /$ respcare. 03753

\section{QUICK LOOK}

\section{Current knowledge}

COPD is a leading cause of morbidity and mortality worldwide. Diagnosis is based on history, symptoms, and spirometry. There are situations in which spirometry is unavailable or cannot be performed, potentially delaying diagnosis and treatment.

\section{What this paper contributes to our knowledge}

In a small group of subjects with respiratory disease, serum biomarkers diagnosed COPD with a reasonable sensitivity and specificity. Surfactant protein D was the most reliable marker in smokers, whereas ceruloplasmin ferroxidase activity was more accurate in nonsmokers. A combination of these 2 markers was able to rule in or rule out subjects for COPD diagnosis.

\section{Methods}

\section{Subject Selection and Procedure}

In this observational study, we compared analytes that are likely to be related to COPD between subjects with COPD and subjects with normal lung function. The COPD group consisted of 96 stable subjects with COPD diagnosed according to GOLD guidelines, selected from patients reporting symptoms of the disease to the respiratory out-patient department of the Cardio-Thoracic Centre in Pune, India. The control group consisted of 96 age- and sex-matched subjects with normal lung function, selected from patients who came for routine checkups and the annual medical board in the Department of Biochemistry of the Armed Forces Medical College in Pune, India, from December 2010 to February 2013. Both groups had an equal number of smokers (48 smokers) and nonsmokers (48 nonsmokers). The clinical assessment at the time of presentation in terms of signs and symptoms and relevant investigations was recorded in a pro forma. The study was approved by the institutional ethics committee, and written informed consent was obtained from the subjects.

Exclusion Criteria. Patients diagnosed with chronic respiratory failure, asthma, coronary artery disease, and diffuse parenchymal lung disease; patients on long-term oxygen therapy; or patients who were unable to undergo spirometry were excluded from the COPD group. Similarly, patients with a past history of any respiratory problem or lung disease or who received inhaled bronchodilators or corticosteroids were excluded from the control group. 
Diagnosis of COPD. COPD was diagnosed by a respiratory physician from the dedicated government hospital, the Cardio-Thoracic Centre. The Department of Respiratory Medicine of the Cardio-Thoracic Centre is headed by a specialist with $>20 \mathrm{y}$ of experience, who is assisted by other faculty. In addition to the MD course in respiratory medicine, this department also conducts a 6-month specially trained nursing assistant course in respiratory medicine. Upon successful completion of this course, these specially trained nursing assistants conduct spirometry in the Cardio-Thoracic Centre under the supervision of the faculty.

All subjects answered a questionnaire on demographic characteristics (from which an initial clinical impression of the diagnosis was made) and then underwent spirometry for confirmation of COPD. Throughout this study, a JAEGGER computerized body plethysmograph (MasterScreen, Viasys Healthcare, Palm Springs, California) was used. Standardization of spirometry was done based on the 2005 ATS/ERS task force joint statement on standardization of spirometry. ${ }^{30}$ Subjects were asked not to use shortacting bronchodilators (eg, the $\beta$-agonist salbutamol or the anticholinergic agent ipratropium bromide) within $4 \mathrm{~h}$ of testing, long-acting bronchodilators (salmeterol or formoterol) within $12 \mathrm{~h}$ of testing, and oral therapy (theophylline or slow-release $\beta$ agonists) within 24 h of testing. Subjects with a clinical diagnosis of COPD based on evaluation as per the study protocol underwent post-bronchodilator spirometry with $400 \mu \mathrm{g}$ of salbutamol via a pressurized metered-dose inhaler with a spacer device. Subjects held their breath after complete inhalation for $>10 \mathrm{~s}$, and spirometry was performed $15 \mathrm{~min}$ after drug administration. Three tests meeting the within- and between-maneuver acceptability criteria were recorded. The presence of post-bronchodilator $\mathrm{FEV}_{1} / \mathrm{FVC}$ of $<0.70(70 \%)$ was used to confirm COPD. ${ }^{31}$ The Smoking Index, used to evaluate smoking in people in India, was used to quantify smoke exposure in study subjects. ${ }^{32}$

\section{Sample Collection and Storage}

Fasting, venous 5-mL samples in plain gel BD Vacutainers (Becton Dickinson, Franklin Lakes, New Jersey) and 4-mL samples in heparin BD Vacutainers were obtained. The heparin samples were immediately centrifuged at 2,000 rpm for $5 \mathrm{~min}$, and plasma was separated, aliquoted, and stored immediately at $-80^{\circ} \mathrm{C}$ until estimation of glutathione peroxidase. Serum was separated by centrifugation at 2,000 rpm for $5 \mathrm{~min}$. Ferroxidase activity was determined immediately, whereas the remaining aliquots were stored at $-80^{\circ} \mathrm{C}$ until estimation of other analytes.

\section{Analyte Measurement}

Ceruloplasmin ferroxidase activity was determined by the kinetic method (Government of India Patent 192356) of Somani and Ambade ${ }^{33}$ on a fully automated analyzer (Transasia Bio-Medicals, Mumbai, India) set at: an assay type of rate A; a primary wavelength of $376 \mathrm{~nm}$; assay points of $0,0,15$, and 18 cycles; a sample volume of $10 \mu \mathrm{L}$; reagent 1 at $200 \mu \mathrm{L}$; reagent 2 at $30 \mu \mathrm{L}$; and factor 2010. For reagent 1 , chromogen $(0.5 \mathrm{mmol} / \mathrm{L})$ was made by dissolving $159.65 \mathrm{mg}$ of norfloxacin in $1 \mathrm{~L}$ of acetate buffer $(0.45 \mathrm{~mol} / \mathrm{L}, \mathrm{pH} 5.4)$ containing $0.2 \%$ Triton X-100. For reagent 2 , substrate $(2.04 \mathrm{mmol} / \mathrm{L})$ was made by sequentially dissolving $320 \mathrm{mg}$ of dithiothreitol and $800 \mathrm{mg}$ of $\mathrm{Fe}\left(\mathrm{NH}_{4}\right)_{2}\left(\mathrm{SO}_{4}\right)_{2} \cdot 6 \mathrm{H}_{2} \mathrm{O}$, in $1 \mathrm{~L}$ of deionized water. The principle behind this estimation is that the ferroxidase activity oxidizes ferrous to ferric ion, which complexes with chromogen to form a complex measured kinetically at $376 \mathrm{~nm}$.

Glutathione peroxidase activity was measured with a glutathione peroxidase assay kit (catalog number 703102, Cayman Chemical, Ann Arbor). Glutathione peroxidase catalyzes the oxidation of glutathione by cumene hydroperoxide. In the presence of glutathione reductase and reduced nicotinamide adenine dinucleotide phosphate hydrogen, the oxidized glutathione is immediately reconverted to the reduced form with concomitant oxidation of reduced nicotinamide adenine dinucleotide phosphate hydrogen to nicotinamide adenine dinucleotide phosphate. With this kit, the decrease in absorbance at $340 \mathrm{~nm}$ is measured and is directly proportional to the glutathione peroxidase activity in the sample expressed as U/L.

SPD was estimated using an enzyme-linked immunosorbent assay (ELISA) kit for human pulmonary SPD (catalog number E1039Hu, EIAab, Wuhan, China). This sandwich ELISA employs a microtiter plate precoated with an antibody specific to SPD. Standards/samples are added with a biotin-conjugated antibody specific for SPD, followed by avidin conjugated to horseradish peroxidase. $\mathrm{Bi}$ otin-conjugated antibody and horseradish peroxidase-conjugated avidin exhibit a change in color proportional to SPD concentration with the addition of $3,3^{\prime}, 5,5^{\prime}$-tetramethylbenzidine only in SPD-containing wells. Concentrations of SPD were determined by a standard curve in $\mathrm{ng} / \mathrm{L}$.

Alpha-1 antitrypsin was estimated with an ELISA kit for human alpha-1 antitrypsin (catalog number E91697Hu, Uscn Life Science, Houston, Texas). This sandwich ELISA employs a microtiter plate precoated with an antibody specific to alpha-1 antitrypsin. Standards/samples are added with a biotin-conjugated antibody specific for alpha- 1 antitrypsin, followed by avidin conjugated to horseradish peroxidase. With this kit, biotin-conjugated antibody and horseradish peroxidase-conjugated avidin exhibit a change in color proportional to alpha-1 antitrypsin concentration 
Table 1. Characteristics of Study Subjects

\begin{tabular}{|c|c|c|}
\hline Parameter & COPD Group $(n=96)$ & Control Group $(n=96)$ \\
\hline Age, mean \pm SD y & $67.7 \pm 8.9$ & $59.8 \pm 12.2$ \\
\hline $\mathrm{FEV}_{1}$, mean $\pm \mathrm{SD} \mathrm{L}$ & $1.28 \pm 0.46$ & NA \\
\hline $\mathrm{FVC}$, mean $\pm \mathrm{SD} \mathrm{L}$ & $2.22 \pm 0.71$ & NA \\
\hline $\mathrm{FEV}_{1} / \mathrm{FVC}$, mean $\pm \mathrm{SD}$ & $0.57 \pm 0.07$ & NA \\
\hline $\mathrm{FEV}_{1}$, mean $\pm \mathrm{SD} \%$ predicted & $49.42 \pm 17.14$ & NA \\
\hline Smokers, $n(\%)$ & $48(50)$ & $48(50)$ \\
\hline Smoking Index score, mean \pm SD & $555.2 \pm 321.3$ & $531.1 \pm 583.4$ \\
\hline
\end{tabular}

with the addition of $3,3^{\prime}, 5,5^{\prime}$-tetramethylbenzidine only in alpha-1 antitrypsin-containing wells. Concentrations of alpha- 1 antitrypsin were determined by a standard curve in $\mathrm{ng} / \mathrm{mL}$ and converted to $\mathrm{mg} / \mathrm{dL}$ by multiplying with a dilution factor $(40,000)$.

Superoxide dismutase 3 was estimated with an ELISA kit for human superoxide dismutase 3 (extracellular, catalog number E8710h, EIAab). This competitive ELISA employs a microtiter plate precoated with an antibody specific to superoxide dismutase 3 . During incubation, superoxide dismutase 3 in standards/samples competes with the fixed amount of biotin-conjugated superoxide dismutase 3 for sites on a precoated monoclonal antibody specific to superoxide dismutase 3. Avidin conjugated to horseradish peroxidase is added, followed by 3,3',5,5' -tetramethylbenzidine. Biotin-conjugated antibody and horseradish peroxidase-conjugated avidin exhibits a change in color only in superoxide dismutase 3 -containing wells. The level of superoxide dismutase 3 was determined by a standard curve in $\mathrm{U} / \mathrm{L}$.

Catalase was estimated with an ELISA kit for human catalase (catalog number E0242h, EIAab). The principle of this competitive ELISA is similar to that of the superoxide dismutase 3 estimation. The levels of catalase were determined in $\mathrm{U} / \mathrm{L}$.

C-reactive protein was estimated with an ELISA kit for C-reactive protein (catalog number CAN-CRP-4360, Diagnostics Biochem Canada, Dorchester, Ontario, Canada). This sandwich ELISA employs a monoclonal antibody specific for C-reactive protein immobilized on a microwell plate and another monoclonal antibody specific for a different region of $\mathrm{C}$-reactive protein that is conjugated to horseradish peroxidase. C-reactive protein from the sample/standards is allowed to bind to the plate, following by washing and incubation with the horseradish peroxidase conjugate. Washing followed by addition of $3,3^{\prime}, 5,5^{\prime}$-tetramethylbenzidine results in color proportional to the concentration of C-reactive protein determined by a standard curve in $\mathrm{ng} / \mathrm{mL}$.

\section{Statistical Analysis}

Statistical analysis was performed using SPSS 17 (SPSS, Chicago, Illinois). Results are expressed as mean \pm SD. Analyte levels were compared between different groups using the Levene test for equality of variances and an unpaired 2-tailed $t$ test. A receiver operating characteristic curve was generated to determine the cutoff value, sensitivity and specificity at that cutoff value, and area under the curve. Positive and negative likelihood ratios (LRs) were also calculated for each analyte and for combinations of analytes. $P<.05$ was accepted as statistically significant.

\section{Results}

In the COPD group, the ratio of males to females was $73: 23$, and the mean age was $67.65 \pm 8.9$ y (range $45-$ $97 \mathrm{y}$ ). In the control group, the ration of males to females was 73:23, and the mean age was $59.82 \pm 12.17 \mathrm{y}$ (range 27-90 y). The number of males and females who were nonsmokers (27 and 21, respectively) and smokers (46 and 2 , respectively) in both groups was also matched. Spirometry parameters, severity according to GOLD staging, and comorbidities of subjects with COPD are summarized in Tables 1-3. As none of the control subjects in this study had respiratory problems or lung diseases or were receiving inhaled bronchodilators or corticosteroids, spirometry in this group was not conducted, in accordance with the guidelines of the American College of Physicians, American College of Chest Physicians, ATS, and ERS. ${ }^{34}$ All subjects with COPD were stable, and $77 \%$ were non-admitted out-patient cases visiting the hospital for routine checkups and free medicines. The remaining $23 \%$ of subjects with COPD were admitted to the Cardio-Thoracic Centre for other causes.

The World Health Organization recommends that patients with COPD be screened for alpha- 1 antitrypsin deficiency. ${ }^{6}$ The level of alpha- 1 antitrypsin in all subjects was estimated: $157 \pm 55 \mathrm{mg} / \mathrm{dL}$ (range $86-$ 
Table 2. Spirometric Data and Severity Per GOLD Staging of Subjects With COPD

\begin{tabular}{|c|c|c|c|c|}
\hline Gold Stage & Subjects, $n(\%)$ & $\begin{array}{l}\mathrm{FEV}_{1}, \% \\
\text { Predicted* }\end{array}$ & $\mathrm{FEV}_{1}, \mathrm{~L}^{*}$ & $\mathrm{FVC}, \mathrm{L}^{*}$ \\
\hline GOLD 1: mild $\left(\mathrm{FEV}_{1} \geq 80 \%\right.$ predicted $)$ & $7(7.3)$ & $81.92 \pm 1.26$ & $1.96 \pm 0.16$ & $3.07 \pm 0.19$ \\
\hline GOLD 2: moderate $\left(50 \% \leq \mathrm{FEV}_{1}<80 \%\right.$ predicted $)$ & $35(36.5)$ & $62.1 \pm 7.5$ & $1.62 \pm 0.24$ & $2.77 \pm 0.41$ \\
\hline GOLD 3: severe $\left(30 \% \leq \mathrm{FEV}_{1}<50 \%\right.$ predicted $)$ & $42(43.7)$ & $41.05 \pm 5.4$ & $1.02 \pm 0.33$ & $1.78 \pm 0.51$ \\
\hline GOLD 4: very severe $\left(\mathrm{FEV}_{1}<30 \%\right.$ predicted $)$ & $12(12.5)$ & $22.87 \pm 6.1$ & $0.83 \pm 0.35$ & $1.64 \pm 0.6$ \\
\hline Total & $96(100)$ & $49.42 \pm 17.14$ & $1.28 \pm 0.46$ & $2.22 \pm 0.71$ \\
\hline
\end{tabular}

Table 3. Comorbidities in Subjects With COPD

\begin{tabular}{lr}
\hline \hline \multicolumn{1}{c}{ Parameter } & $n$ \\
\hline Non-admitted out-patient cases & 74 \\
Subjects admitted to hospital for cause other than COPD & 22 \\
Subjects without any comorbidity & 61 \\
Subjects with only one comorbidity & \\
Hypertension & 13 \\
Diabetes mellitus & 5 \\
Deep venous thrombosis & 1 \\
Dilated cardiomyopathy & 1 \\
Thyromegaly & 1 \\
Spondylitis & 1 \\
Renal calculi & 1 \\
Tachycardia & 1 \\
Osteoporosis & 1 \\
Atrial fibrillation & 2 \\
Subjects with 2 comorbidities & 4 \\
Hypertension with diabetes mellitus & 1 \\
Hypertension with seizure & 1 \\
Hypertension with OSA & 1 \\
Hypertension with peripheral artery disease & 1 \\
Subjects with 3 comorbidities & \\
Hypertension with diabetes mellitus and OSA & \\
& \\
\hline OSA = obstructive sleep apnea & \\
\hline
\end{tabular}

$293 \mathrm{mg} / \mathrm{dL}$ ) in the control group and $194 \pm 54 \mathrm{mg} / \mathrm{dL}$ (range 54-298 $\mathrm{mg} / \mathrm{dL}$ ) in the COPD group. A serum concentration of alpha-1 antitrypsin below $15-20 \%$ of the normal value is suggestive of alpha- 1 antitrypsin deficiency. ${ }^{6}$ Considering a mean of $157 \mathrm{mg} / \mathrm{dL}$ in the subjects with normal lung function, a level below $31.4 \mathrm{mg} / \mathrm{dL}$ ( $20 \%$ of $157 \mathrm{mg} / \mathrm{dL}$ ) would be suggestive of alpha- 1 antitrypsin deficiency, and accordingly, none of the subjects with COPD could be categorized as alpha- 1 antitrypsin-deficient.

Levels of superoxide dismutase 3 were found to be significantly decreased, whereas levels of ferroxidase activity, SPD, glutathione peroxidase, and C-reactive protein were found to be increased in the COPD group, with substantial mean differences (Table 4). Similar differences were found in the nonsmokers and smokers of both groups (Table 5). For catalase, the difference was not significant.

Receiver operating characteristic curves were generated for the analytes, which showed significant differences between the COPD and control groups for all subjects (without considering the smoking status), smokers, and nonsmokers (Figs. 1-5). The sensitivity, specificity, cutoff value, area under the curve, and positive and negative LRs for each analyte for all subjects, smokers, and nonsmokers are shown in Tables 6 and 7.

For all subjects, the area under the curve was highest for ferroxidase activity (0.92), followed by glutathione peroxidase (0.92), SPD (0.91), and C-reactive protein (0.84). At their optimal cutoff values of $1,141.05 \mathrm{IU} / \mathrm{L}, 63.25 \mathrm{U} / \mathrm{L}$, $104.45 \mathrm{ng} / \mathrm{mL}$, and 4,608.12 ng/mL, ferroxidase activity, glutathione peroxidase, SPD, and C-reactive protein showed a sensitivity and specificity of 82 and $94 \%, 89$ and $83 \%, 80$ and $86 \%$, and 75 and $81 \%$, respectively.

Similar results were seen for the nonsmoking subjects with COPD. The area under the curve was highest for ferroxidase activity $(0.95)$, followed by glutathione peroxidase (0.94), SPD (0.91) and C-reactive protein (0.85). At their cutoff values of $1,133.05 \mathrm{IU} / \mathrm{L}, 63.59 \mathrm{U} / \mathrm{L}$, $76.13 \mathrm{ng} / \mathrm{mL}$, and $3,186.3 \mathrm{ng} / \mathrm{mL}$, ferroxidase activity, glutathione peroxidase, SPD, and C-reactive protein showed a sensitivity and specificity of 90 and $98 \%, 88$ and $92 \%, 94$ and $73 \%$, and 77 and $83 \%$, respectively.

However, for smoking subjects with COPD, the area under the curve was highest for SPD (0.94), followed by glutathione peroxidase $(0.90)$, ferroxidase activity $(0.89)$, and C-reactive protein (0.82). At their optimal cutoff values of $104.45 \mathrm{ng} / \mathrm{mL}, 65.3 \mathrm{IU} / \mathrm{L}, 1,147.25 \mathrm{IU} / \mathrm{L}$, and $6,209.5 \mathrm{ng} / \mathrm{mL}$, SPD, glutathione peroxidase, ferroxidase activity, and C-reactive protein showed a sensitivity and specificity of 96 and $85 \%, 88$ and $79 \%, 75$ and $92 \%$, and 67 and $100 \%$, respectively.

Instead of a single marker, combinations of biomarkers were found to attain a sensitivity or specificity of $>95 \%$ at the cutoff values of the respective markers depending upon the combination and the criteria used for diagnosis of COPD. The combinations of markers were also found to 
Table 4. Descriptive Statistics of Analytes in Study Subjects

\begin{tabular}{lccc}
\hline \hline \multicolumn{1}{c}{ Analyte } & $\begin{array}{c}\text { COPD Group } \\
(n=96)\end{array}$ & Control Group $(n=96)$ & $\begin{array}{c}\text { Mean } \\
\text { Difference }\end{array}$ \\
\hline Ferroxidase activity, IU/L & $1,380.22 \pm 284.23$ & $929.79 \pm 156.99$ & $450.43 \pm 33.14$ \\
Catalase, U/L & $54.36 \pm 27.75$ & $52.64 \pm 23.38$ & $1.72 \pm 3.70$ \\
Superoxide dismutase 3, U/L & $167.62 \pm 58.87$ & $244.79 \pm 69.12$ & $-77.17 \pm 9.27$ \\
SPD, ng/mL & $149.58 \pm 53.47$ & $74.84 \pm 30.33$ & $74.74 \pm 6.27$ \\
Glutathione peroxidase, U/L & $89.73 \pm 27.84$ & $50.95 \pm 15.30$ & $38.77 \pm 3.24$ \\
C-reactive protein, ng/mL & $7,933.1 \pm 4,212.7$ & $2,896.9 \pm 1,739.8$ & .001 \\
& & .001 \\
Data for the COPD and control groups are expressed as mean \pm SD. Mean difference (COPD group minus control group) is expressed as mean \pm SE. & .001 \\
SPD = surfactant protein D & & & .001 \\
& & & \\
\hline
\end{tabular}

Table 5. Comparison of Analyte Levels Between Nonsmokers in the COPD and Control Groups and Between Smokers in the COPD and Control Groups

\begin{tabular}{|c|c|c|c|c|}
\hline \multirow[b]{2}{*}{ Analyte } & \multicolumn{2}{|c|}{ Nonsmokers } & \multicolumn{2}{|c|}{ Smokers } \\
\hline & $\begin{array}{c}\text { Mean } \\
\text { Difference }\end{array}$ & $P$ & $\begin{array}{c}\text { Mean } \\
\text { Difference }\end{array}$ & $P$ \\
\hline Ferroxidase activity, IU/L & $456.85 \pm 40.81$ & .001 & $444.01 \pm 52.11$ & .001 \\
\hline Catalase, U/L & $0.29 \pm 4.69$ & .95 & $3.15 \pm 5.78$ & .59 \\
\hline Superoxide dismutase $3, \mathrm{U} / \mathrm{L}$ & $-90.97 \pm 13.84$ & .001 & $-63.37 \pm 11.76$ & .001 \\
\hline $\mathrm{SPD}, \mathrm{ng} / \mathrm{mL}$ & $67.25 \pm 8.10$ & .001 & $82.23 \pm 8.96$ & .001 \\
\hline Glutathione peroxidase, U/L & $40.95 \pm 4.76$ & .001 & $36.60 \pm 4.36$ & .001 \\
\hline C-reactive protein, $\mathrm{ng} / \mathrm{mL}$ & $5376.6 \pm 638.9$ & .001 & $4695.9 \pm 660.3$ & .001 \\
\hline
\end{tabular}

have comparatively higher positive LRs and lower negative LRs, as shown in Table 8.

If either of the 2 markers in the combination, greater or less than its cutoff value, was used as a criterion for diagnosis of COPD, it was found to give $>95 \%$ sensitivity. And if both markers in the combination, greater or less than their cutoff values, were used as a criterion, then specificity was $>95 \%$.

\section{Discussion}

This study clearly shows that biomarkers have a potential to differentiate between subjects with normal lung function and subjects with COPD and can be employed in the diagnosis of COPD with considerable sensitivity and specificity. Our results suggest different criteria using combinations of markers to rule out or rule in COPD.

Lock-Johansson et $\mathrm{al}^{35}$ recently reported that the limitations of spirometry and clinical history have prompted researchers to investigate biomarkers of COPD and included SPD and C-reactive protein in the panel of biomarkers. Bowler ${ }^{36}$ stated that clinical research in COPD has been hampered by the lack of validated blood biomarkers and discussed the evidence supporting SPD as a
COPD biomarker. Sin et al ${ }^{37}$ commented that the scarcity of a well-validated, robust, and easily obtainable intermediate end point such as serum biomarkers is a major impediment in the development of novel drugs for COPD and reported SPD as a promising systemic biomarker fulfilling some of the criteria of a biomarker. Dickens et al ${ }^{26}$ (ECLIPSE study investigators) also expressed the need for biomarkers to better characterize individuals with COPD and to aid in the development of therapeutic interventions. These comments indicate the need for biomarkers, and our study was an attempt to explore different analytes as biochemical markers of COPD.

Extracellular superoxide dismutase or superoxide dismutase 3 , the last discovered superoxide dismutase isoform that binds lung matrix components, inhibiting their fragmentation in response to oxidative stress, ${ }^{38-40}$ is the primary extracellular lung antioxidant enzyme. ${ }^{41,42}$ It protects the extracellular matrix during lung injury ${ }^{43-46}$ and accounts for the majority of superoxide dismutase activity in airways and vessels. ${ }^{47,48}$ Yen et $\mathrm{al}^{49}$ suggested the therapeutic utility of superoxide dismutase 3 to reduce oxidative injury to lungs. With the availability of ELISA for superoxide dismutase 3, this specific isoform was estimated in this study. Our results demonstrated sufficiently 

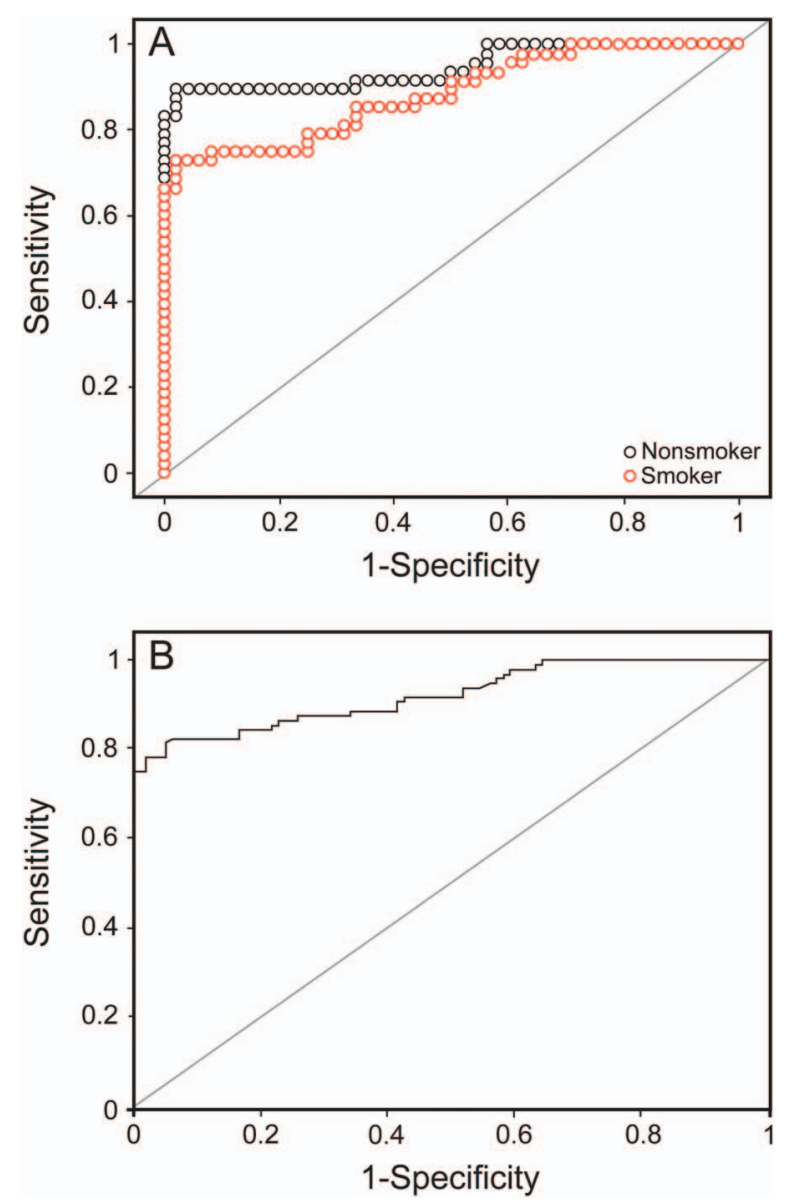

Fig. 1. Receiver operating characteristic curves for ferroxidase activity in smokers and nonsmokers (A) and all subjects (B).

decreased levels of serum superoxide dismutase 3 in the COPD group compared with the control group and are in agreement with those of Zeng et al, ${ }^{50}$ Gavali et al, ${ }^{51}$ and Tavilani et al. ${ }^{52}$ This decreased activity in subjects with COPD probably results from an increase in consumption of antioxidants..$^{53} \mathrm{We}$ found a superoxide dismutase $3 \mathrm{lev}$ els of $244.79 \pm 69.12 \mathrm{U} / \mathrm{L}$ in the control group (see Table 4), whereas Chakraborty et al ${ }^{54}$ reported plasma superoxide dismutase levels of $4.06 \pm 0.26 \mathrm{U} / \mathrm{mL}$, KoturStevuljevic et al ${ }^{55}$ found plasma superoxide dismutase levels of $153 \pm 36 \mathrm{U} / \mathrm{L}$ in non-coronary heart disease control subjects, and Comhair et al ${ }^{56}$ reported a mean serum superoxide dismutase level of $2.75 \mathrm{U} / \mathrm{mL}$. These differences may be due to differences in measurement methods. Chakraborty et al ${ }^{54}$ estimated superoxide dismutase following the method of Kakkar et al, ${ }^{57}$ whereas we estimated superoxide dismutase 3 instead of superoxide dismutase with an ELISA kit.

Glutathione peroxidase is the principal antioxidant enzyme in animal cells for $\mathrm{H}_{2} \mathrm{O}_{2}$ detoxification, as catalase has much lower affinity for $\mathrm{H}_{2} \mathrm{O}_{2}$ compared with glutathione peroxidase. ${ }^{58-60}$ The higher level of serum glutathione
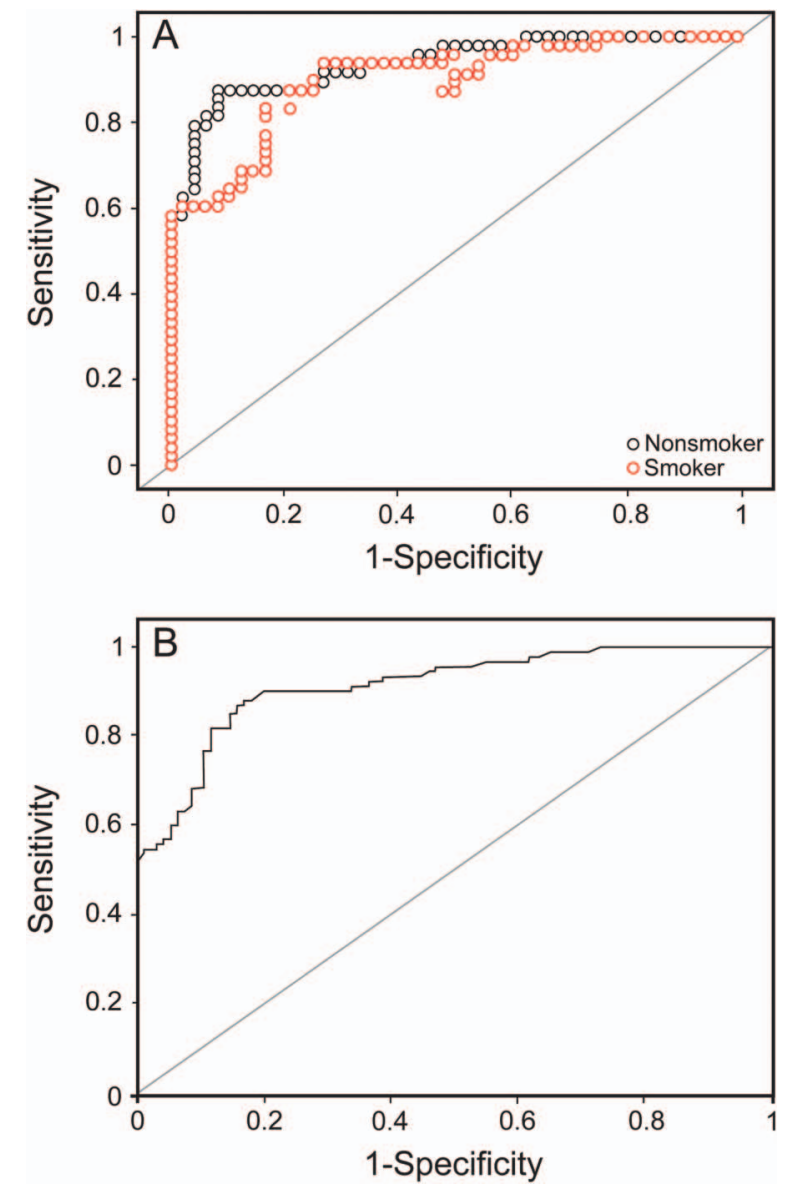

Fig. 2. Receiver operating characteristic curves for glutathione peroxidase in smokers and nonsmokers (A) and all subjects (B).

peroxidase in subjects with COPD compared with control subjects (see Table 4) was similar to that reported by Nadeem et al. ${ }^{61}$ One study showed that, as an antioxidant defense mechanism, glutathione peroxidase activity was increased in plasma, whereas erythrocyte glutathione peroxidase activity (intracellular) was decreased due to high levels of hydroxyl radical and superoxide anions in the erythrocytes that inactivated glutathione peroxidase. ${ }^{62}$ We found control glutathione peroxidase levels of $50.95 \pm 15.30 \mathrm{U} / \mathrm{L}$, which is higher than that found by Comhair et al, ${ }^{56}$ who reported a mean serum glutathione peroxidase level of $0.03 \mathrm{U} / \mathrm{mL}(n=10)$. However, Alegría et al ${ }^{63}$ reported plasma glutathione peroxidase levels of $196-477 \mathrm{U} / \mathrm{L}$ in a healthy population $(n=287)$ using a modification of the method of Paglia and Valentine. ${ }^{64}$

We found no difference in serum catalase levels. This results agrees with that of Hackett et al, ${ }^{65}$ who reported that humans do not up-regulate catalase genes in the airway epithelium in response to oxidative stress.

Ceruloplasmin is a major extracellular antioxidant in serum, and its antioxidant action has been proposed as a crucial function, with the highest oxidizing activity found 

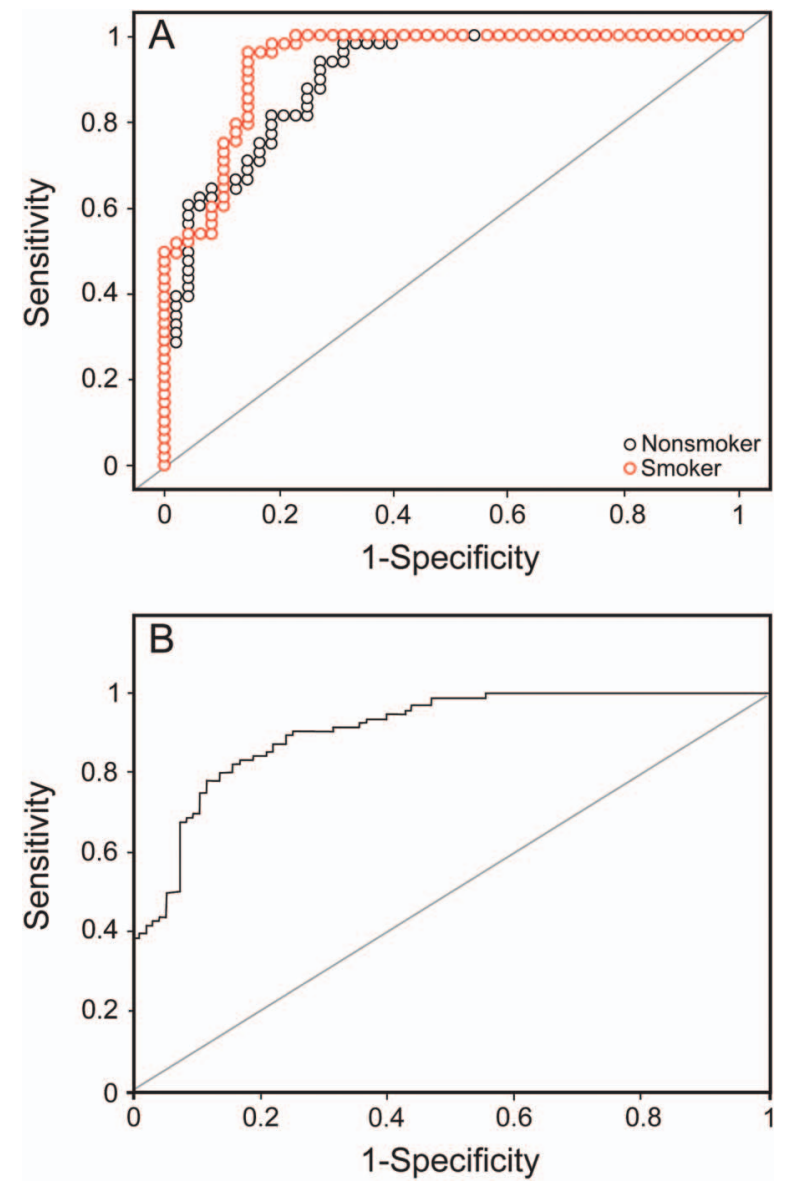

Fig. 3. Receiver operator characteristic curves for surfactant protein $\mathrm{D}$ in smokers and nonsmokers (A) and all subjects (B).

for $\mathrm{Fe}^{2+}$, which led to ferroxidase being proposed as an alternative name. ${ }^{66,67}$ Ceruloplasmin inhibits $\mathrm{Fe}^{2+}$-stimulated lipid peroxidation. ${ }^{68}$ It protects antiproteases, thereby preserving lung elasticity and expiratory flows, and it also plays a role in preventing lung injury, so an abnormality in its oxidative inhibition could be involved in the pathogenesis of COPD. ${ }^{69}$ In this study, the specific ferroxidase activity of ceruloplasmin was estimated. Increased ferroxidase activity in subjects with COPD (see Table 4) is in agreement with results obtained by Verrills et al, ${ }^{70}$ who found that a panel of biomarkers (alpha-2 macroglobulin, haptoglobin, ceruloplasmin, and hemopexin) were able to discriminate between asthma, COPD, and controls with statistical significance. The increased ferroxidase activity in subjects with COPD might be a compensatory rise in the antioxidant defense mechanism, as ferroxidase activity is a measure of antioxidant activity. ${ }^{71}$

C-reactive protein levels were reported as strongly associated with 6-min walk distance in stable subjects with COPD. ${ }^{72}$ Dahl et al ${ }^{73}$ showed that $\mathrm{C}$-reactive protein levels in the stable state were a strong long-term predictor of future outcomes in subjects with COPD. We found in-
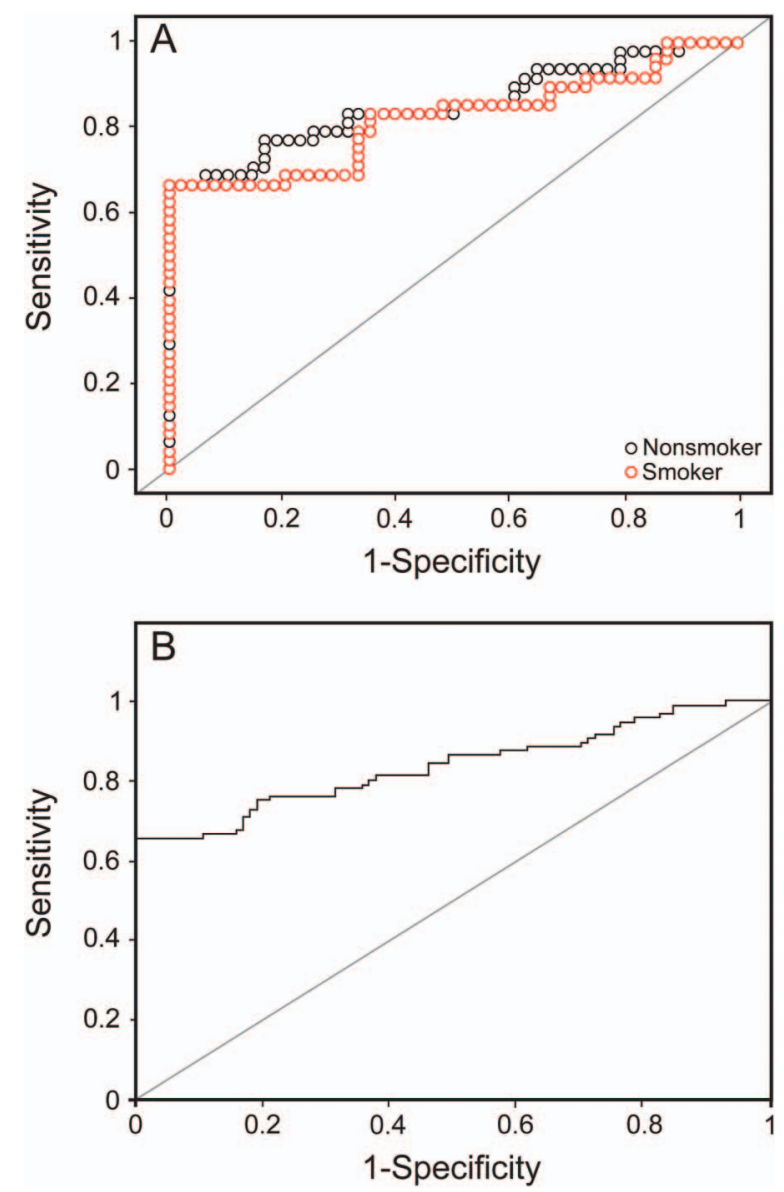

Fig. 4. Receiver operating characteristic curves for C-reactive protein in smokers and nonsmokers (A) and all subjects (B).

creased C-reactive protein levels in subjects with COPD, which is in agreement with results obtained by Dahl et al, ${ }^{73}$ Akbulut et al, ${ }^{74}$ van Durme et al, ${ }^{75}$ and Deng et al, ${ }^{76}$ who reported C-reactive protein levels higher in stable subjects with COPD and suggested its utility as a long-term predictor of future outcomes. C-reactive protein levels of $2,896.89 \pm 1,739.76 \mathrm{ng} / \mathrm{mL}$ in subjects with normal lung function (see Table 4) are similar to those reported by Akbulut et al. ${ }^{74}$

SPD, found predominantly in the endoplasmic reticulum of type- 2 alveolar cells and in the secretory granules of Club cells in lungs, ${ }^{36}$ has the highest expression in the distal airways and alveoli in human tissues and plays a central role in pulmonary host defense. ${ }^{77}$ SPD levels of $74.84 \pm 30.33 \mathrm{ng} / \mathrm{mL}$ in control subjects is in agreement with results obtained by Janssen et al. ${ }^{78}$ The increased SPD levels in subjects with COPD is in agreement with results of Lomas et al, ${ }^{79}$ who found serum SPD to be a biomarker of COPD in the ECLIPSE cohort, Zaky et al, ${ }^{80}$ who suggested SPD as a promising biomarker for severity in stable subjects with COPD, and Liu et al, ${ }^{81}$ who reported significantly increased serum SPD levels in a COPD 

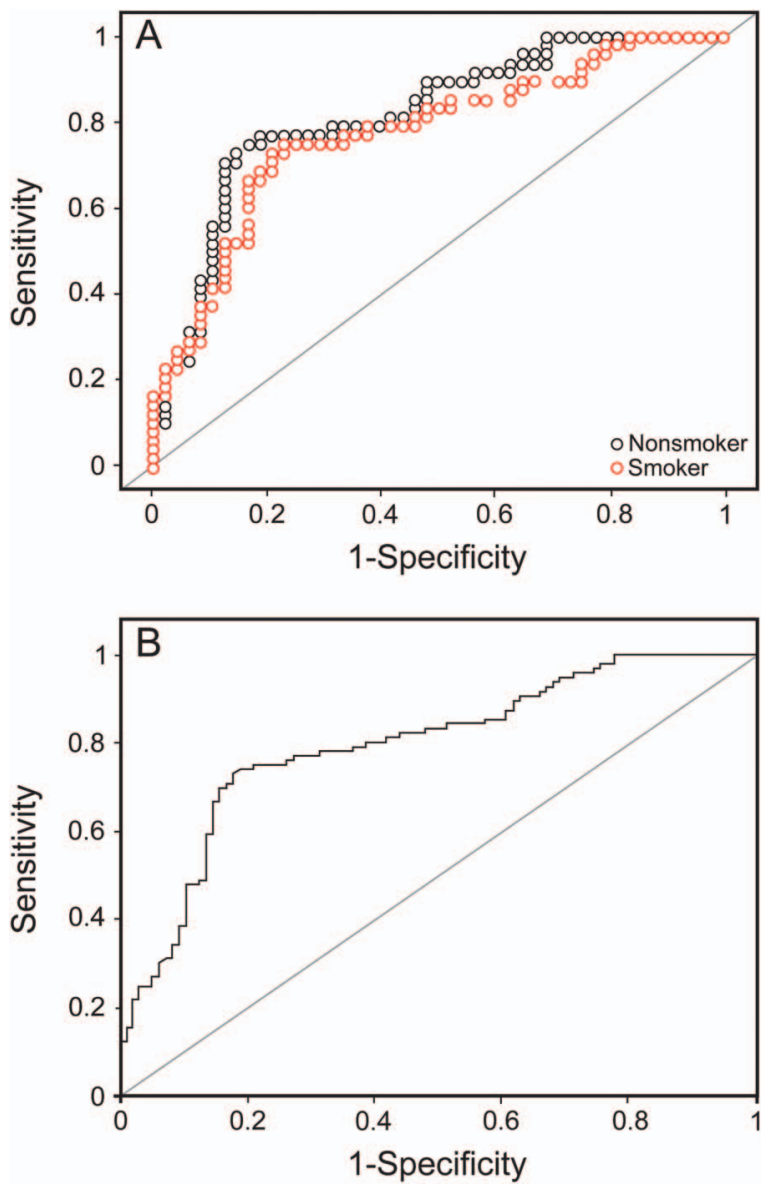

Fig. 5. Receiver operating characteristic curves for superoxide dismutase 3 in smokers and nonsmokers (A) and all subjects (B).

group compared with a control group. Sin et al ${ }^{82}$ found that $\mathrm{FEV}_{1}$ was inversely associated with serum SPD levels, but not with Club cell protein 16, and reported that circulating SPD levels may be useful biomarkers to track health outcomes in subjects with COPD. It has been reported that SPD has potent protective properties as an antioxidant. ${ }^{83}$ The increased serum SPD in this study might be due to leakage from the lung, which undergoes injury due to oxidative stress in patients with COPD.

After determining the statistical significance and considerable differences in the levels between the COPD and control groups, the next step was to determine the cutoff value of each analyte at which it offers the highest sensitivity (true positive rate) and highest specificity (true negative rate) in the diagnosis of COPD. Accordingly, the receiver operating characteristic curve was generated for 5 analytes (see Figs. 1-5). The area under the curve was determined along with the positive likelihood ratio (chances of diagnosis being correct) and negative likelihood ratio (chances of diagnosis being incorrect) at the derived cutoff value of the marker (see Tables 6 and 7).
Of these 5 analytes, superoxide dismutase 3 had the lowest area under the curve (0.80) and lowest sensitivity $(72.9 \%)$, whereas the others had an area under the curve of $>0.83$, sensitivity of $>75 \%$, and specificity of $>81 \%$ (see Table 6). The same pattern was observed in smokers and nonsmokers (see Table 7). Three analytes (ferroxidase activity, glutathione peroxidase, and SPD) were found to have area under the curve of $>0.90$ with a sensitivity and specificity of $>80 \%$ and appear to be promising markers for COPD diagnosis.

For all subjects, the area under the curve was the highest for ferroxidase activity (0.92), with the highest positive LR of 13.67 and a low negative LR of 0.19 , followed by glutathione peroxidase, SPD, and C-reactive protein, with positive and negative LRs of 3.955.71 and $0.13-0.31$, respectively. For this area under the curve at their cutoff values, ferroxidase activity, glutathione peroxidase, SPD, and C-reactive protein showed a sensitivity and specificity of 94 and $75 \%$ (see Table 6), respectively. Thus, if a subject cannot perform spirometry, then the diagnosis of COPD can be carried out biochemically using the biomarkers ferroxidase activity, glutathione peroxidase, SPD, and C-reactive protein with substantial sensitivity and specificity. At serum ferroxidase activity levels of $>1,141 \mathrm{IU} / \mathrm{L}$, subjects were diagnosed with COPD with a 13.7 times greater chance that they actually had COPD (positive LR 13.67) and only a 0.19 times chance that they were actually non-COPD (negative LR 0.19). Not only are the chances of correct diagnosis considerably high and wrong diagnosis very low, but the criteria also show a sensitivity of $82 \%$ and specificity of $94 \%$. Similarly, subjects with glutathione peroxidase of $>63.25 \mathrm{U} / \mathrm{L}, \mathrm{SPD}$ of $>104.45 \mathrm{ng} / \mathrm{mL}$, and C-reactive protein of $>4,608.12 \mathrm{ng} / \mathrm{mL}$ were diagnosed with COPD with both a sensitivity and specificity of $>75 \%$, positive LR of $>3.9$, and negative LR of $<0.33$ (see Table 6).

For the nonsmoking subjects, the area under the curve was the highest for ferroxidase activity (0.95), with a high positive LR of 45.00 and a low negative LR of 0.10 , followed by glutathione peroxidase, SPD, and C-reactive protein, with positive and negative LRs of 3.48-11.00 and $0.08-0.28$, respectively. At their optimal cutoff values (see Table 7), these markers showed a sensitivity of $87-94 \%$ and specificity of $73-98 \%$. If a subject was a nonsmoker with a serum ferroxidase activity level of $>1,133 \mathrm{IU} / \mathrm{L}$, then based on these criteria, the subject was diagnosed with COPD with a 45 times greater chance that he or she actually had COPD and only a 0.1 times chance that the subject was actually non-COPD. The criteria also showed a high true positive rate of $98 \%$ and a high true negative rate of $90 \%$. Similarly, diagnosis of COPD in nonsmoking subjects could be carried out using the cutoff value of the biomarkers glutathione peroxidase, SPD, and C-reactive 
Table 6. Analyte Cutoff Values Without Consideration of Smoking Status

\begin{tabular}{|c|c|c|c|c|c|c|}
\hline Analyte & Area Under the Curve & Cutoff Value & Sensitivity & Specificity & Positive LR & Negative LR \\
\hline Ferroxidase activity, IU/L & 0.92 & $1,141.05$ & 0.82 & 0.94 & 13.67 & 0.19 \\
\hline Glutathione peroxidase, U/L & 0.92 & 63.25 & 0.89 & 0.83 & 5.24 & 0.13 \\
\hline $\mathrm{SPD}, \mathrm{ng} / \mathrm{mL}$ & 0.91 & 104.45 & 0.80 & 0.86 & 5.71 & 0.23 \\
\hline C-reactive protein, $\mathrm{ng} / \mathrm{mL}$ & 0.84 & $4,608.12$ & 0.75 & 0.81 & 3.95 & 0.31 \\
\hline Superoxide dismutase $3, \mathrm{U} / \mathrm{L}$ & 0.80 & 188.47 & 0.73 & 0.82 & 4.12 & 0.33 \\
\hline $\begin{array}{l}n=96 . \\
\mathrm{LR}=\text { likelihood ratio } \\
\text { SPD = surfactant protein D }\end{array}$ & & & & & & \\
\hline
\end{tabular}

protein, with both a sensitivity and specificity of $>73 \%$, positive LR of $>3.48$, and negative LR of $<0.28$. For smoking subjects, the area under the curve was the highest for SPD, followed by glutathione peroxidase, ferroxidase activity, and C-reactive protein, with positive and negative LRs of 4.19-67.0 and 0.15-0.33, respectively. At their optimal cutoff values, these markers showed a sensitivity of $67-96 \%$ and specificity of $79-100 \%$. Thus, if a subject was a smoker with a serum SPD level of $>104.45 \mathrm{ng} / \mathrm{mL}$, then based on these criteria, the subject was diagnosed with COPD with a 6.4 times greater chance that the subject actually had COPD and only a 0.05 times chance that the subject was actually non-COPD. The criteria also show a high true positive rate of $96 \%$ and a high true negative rate of $85 \%$. Similarly, diagnosis of COPD in smoking subjects could be made using the cutoff values of the biomarkers ferroxidase activity, glutathione peroxidase, and C-reactive protein, with both a sensitivity and specificity of $>67 \%$, positive LR of $>4.19$, and negative LR of $<0.33$ (see Table 7).

For clinicians, to rule out COPD in patients for any clinical management, a high sensitivity is required, and to rule in COPD, a high specificity is required. Accordingly, combinations of biomarkers were tried statistically, and certain combinations were found to attain a sensitivity or specificity of $>95 \%$ and can be used by clinicians to rule in and rule out COPD.

If any one biomarker of a combination, greater than its cutoff value, is used as a criterion for diagnosis of COPD, it exhibits a sensitivity of $>96 \%$, with an extremely low negative LR of $<0.04$, making this as an effective criterion for clinicians to rule out COPD. The effective combinations were ferroxidase activity or glutathione peroxidase, ferroxidase activity or SPD, and SPD or glutathione peroxidase. Thus, irrespective of smoking status, if a subject had neither ferroxidase activity of $>1,141.05 \mathrm{IU} / \mathrm{L}$ nor glutathione peroxidase of $>63.25 \mathrm{U} / \mathrm{L}$, the subject was ruled out as having COPD, with a $<0.0125$ times chance of the diagnosis being wrong, providing much needed confidence to the clinician to rule out COPD. Similarly, if a subject had neither ferroxidase activity of
$>1,141.05 \mathrm{IU} / \mathrm{L}$ nor SPD of $>104.45 \mathrm{ng} / \mathrm{mL}$ (both ferroxidase activity and SPD within the cutoff values), then the subject was ruled out as having COPD, with a $<0.03$ times chance of the diagnosis being wrong. In the case of smoking and nonsmoking subjects, the combinations ferroxidase activity or glutathione peroxidase, ferroxidase activity or SPD, and SPD or glutathione peroxidase greater than their respective cutoff values determined specifically for smokers and nonsmokers (as mentioned in Table 7) exhibited a sensitivity of $>96 \%$ and a specificity $>71 \%$, with an extremely low negative $\mathrm{LR}$ of $<0.03$.

However, if both biomarkers of the combinations ferroxidase activity and SPD, ferroxidase activity and glutathione peroxidase, and SPD and glutathione peroxidase greater than the cutoff values were used as criteria, we obtained a specificity of $>94 \%$, with a high positive LR of $>17.25$, making this as an effective criterion to rule in COPD. Thus, irrespective of smoking status, if a subject had both ferroxidase activity of $>1,141.05 \mathrm{IU} / \mathrm{L}$ and SPD of $>104.45 \mathrm{ng} / \mathrm{mL}$, the subject was diagnosed as having COPD, with a 34 times greater chance that the subject had COPD and only a 0.3 times chance that the subject was non-COPD, thereby offering the required confidence to the clinician to rule in COPD. Both markers of the combinations ferroxidase activity and glutathione peroxidase, ferroxidase activity and SPD, and SPD and glutathione peroxidase greater than their respective cutoff values determined exclusively for smokers and nonsmokers displayed a specificity of $>94 \%$ and sensitivity $>63 \%$, with a high positive LR of $>13.33$ (see Table 8).

This study has several limitations. First, this was a single-center study. Although the subjects were well-characterized, the sample size was not sufficient to be categorized GOLD 1, 2, 3, or 4; therefore, levels of biomarkers in each category could not be statistically presented. The conclusions were drawn based on the statistical findings. Larger multi-center studies with sufficient subjects in each GOLD category are needed in the future to validate these findings. Second, all subjects with COPD were stable, so the effects of exacerbations, hospital admissions, and treat- 

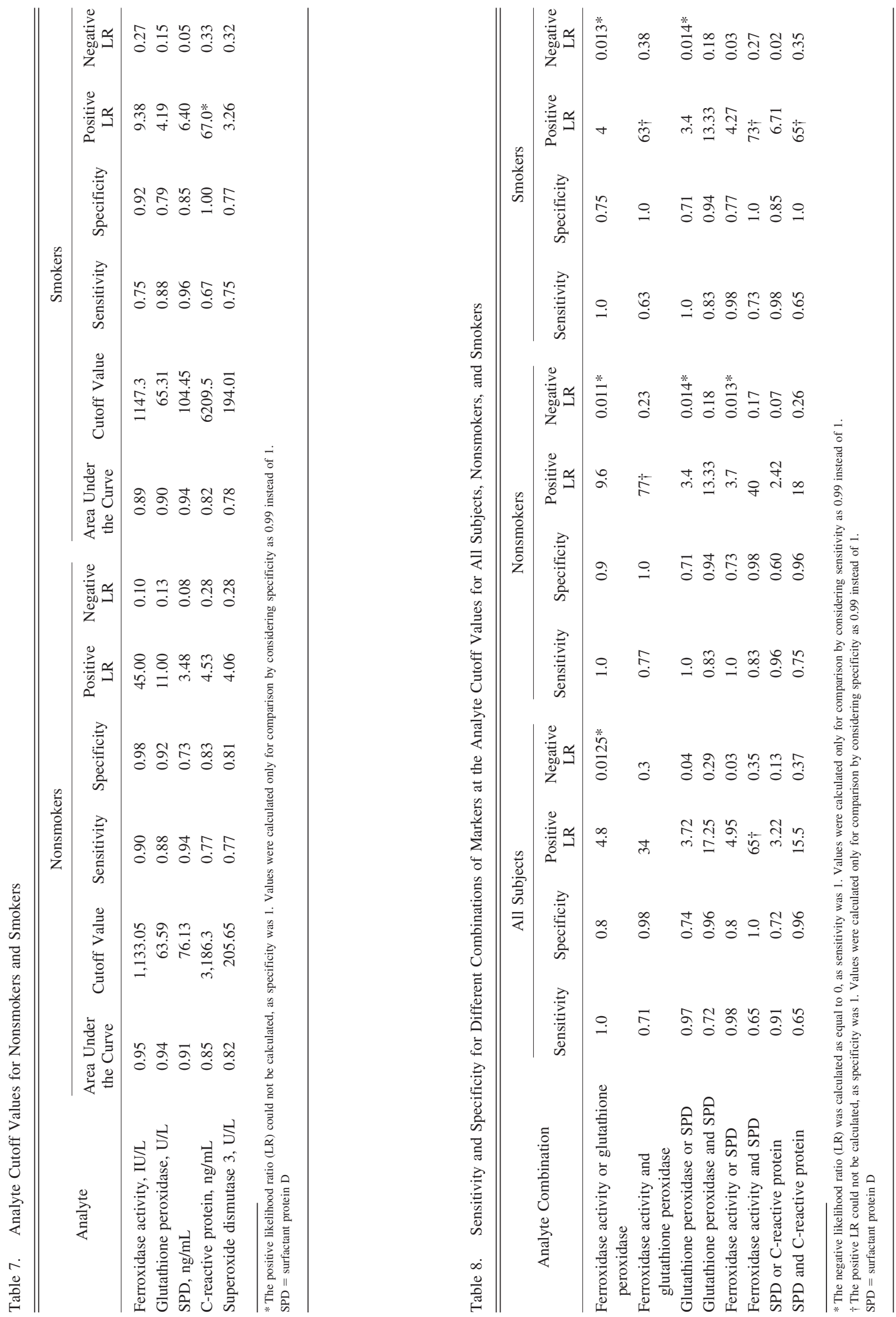


\section{Diagnostic Utility of Biomarkers IN COPD}

ments on biomarker levels could not be determined. Third, we did not measure biomarkers such as Club cell protein 16 , for example; thus, the use of other lung-specific molecules as potential biomarkers of COPD is not certain. Fourth, the physical activity of the subjects and their dietary intake of antioxidants, which might affect the results, and the potential impact of drugs on the biomarkers were not considered.

\section{Conclusions}

Biomarkers can be used reliably in the diagnosis of COPD with appreciable sensitivity and specificity. SPD was the most promising marker in smokers, whereas ferroxidase activity was the most promising in nonsmokers. To rule out COPD, the combination ferroxidase activity or glutathione peroxidase greater than their cutoff values was found to be the most reliable. To rule in COPD, the combination ferroxidase activity and glutathione peroxidase greater than their cutoff values was found to be most promising in both nonsmoking and smoking subjects.

\section{ACKNOWLEDGMENTS}

We thank Dr Prakash Pandare (Department of English, HV Desai College, Pune, India) for assistance in editing the manuscript.

\section{REFERENCES}

1. Rabe KF, Hurd S, Anzueto A, Barnes PJ, Buist SA, Calverley P, et al. Global strategy for the diagnosis, management, and prevention of chronic obstructive pulmonary disease: GOLD executive summary. Am J Respir Crit Care Med 2007;176(6):532-555.

2. Murray CJ, Lopez AD. Alternative projections of mortality and disability by cause 1990-2020: global burden of disease study. Lancet 1997;349(9064):1498-1504.

3. Mathers CD, Loncar D. Projections of global mortality and burden of disease from 2002 to 2030. PLoS Med 2006;3(11):e442.

4. American Thoracic Society, European Respiratory Society. Standards for the diagnosis and management of patients with COPD. http://www. thoracic.org/clinical/copd-guidelines/resources/copddoc.pdf. Accessed October 24, 2014

5. Celli BR, MacNee W. Standards for the diagnosis and treatment of patients with COPD: a summary of the ATS/ERS. Eur Respir J 2004;23(6):932-946.

6. Global Initiative for Chronic Obstructive Lung Disease. Global strategy for the diagnosis, management, and prevention of chronic obstructive pulmonary disease. Updated 2014. http://www.goldcopd.org/uploads/ users/files/GOLD_Report2014_Feb07.pdf. Accessed October 24, 2014.

7. Pauwels RA, Buist AS, Calverley PM, Jenkins CR, Hurd SS, GOLD Scientific Committee. Global strategy for the diagnosis, management, and prevention of chronic obstructive pulmonary disease. NHLBI/WHO Global Initiative for Chronic Obstructive Lung Disease (GOLD) Workshop summary. Am J Respir Crit Care Med 2001;163(5):1256-1276.

8. Falaschetti E, Swanney MP, Crapo RO, Hankinson JL, Jensen RL, Pedersen OF, et al. Diagnosis of COPD. Thorax 2007;62(10):924925; author reply 925 .
9. Viegi G, Pedreschi M, Pistelli F, Di Pede F, Baldacci S, Carrozzi L, Giuntini C. Prevalence of airways obstruction in a general population: ERS vs ATS definition. Chest 2000;117(5 Suppl 2):339S-345S.

10. Lindberg A, Eriksson B, Larsson LG, Rönmark E, Sandström T, Lundbäck B. Seven-year cumulative incidence of COPD in an agestratified general population sample. Chest 2006;129(4):879-885.

11. Bolton CE, Ionescu AA, Edwards PH, Faulkner TA, Edwards SM, Shale DJ. Attaining a correct diagnosis of COPD in general practice. Respir Med 2005;99(4):493-500.

12. Enright PL, Crapo RO. Controversies in the use of spirometry for early recognition and diagnosis of chronic obstructive pulmonary disease in cigarette smokers. Clin Chest Med 2000;21(4):645-652.

13. Ferguson GT, Enright PL, Buist AS, Higgins MW. Office spirometry for lung health assessment in adults: a consensus statement from the National Lung Health Education Program. Chest 2000;117(4):11461161.

14. Schermer T, Eaton T, Pauwels R, van Weel C. Spirometry in primary care: is it good enough to face demands like World COPD Day? Eur Respir J 2003;22(5):725-727.

15. Schermer TR, Jacobs JE, Chavannes NH, Hartman J, Folgering HT, Bottema BJ, van Weel C. Validity of spirometric testing in a general practice population of patients with chronic obstructive pulmonary disease. Thorax 2003;58(10):861-866.

16. Haynes JM. Pulmonary function test quality in the elderly: a comparison with younger adults. Respir Care 2014;59(1):16-21.

17. Hardie JA, Buist AS, Vollmer WM, Ellingsen I, Bakke PS, Mørkve O. Risk of over-diagnosis of COPD in asymptomatic elderly neversmokers. Eur Respir J 2002;20(5):1117-1122.

18. Halliwell B. Antioxidants in human health and disease. Annu Rev Nutr 1996;16:33-50

19. MacNee W. Treatment of stable COPD: antioxidants. Eur Respir Rev 2005;14(94):12-22.

20. Diplock AT, Charleux JL, Crozier-Willi G, Kok FJ, Rice-Evans C, Roberfroid M, et al. Functional food science and defence against reactive oxidative species. Br J Nutr 1998;80(Suppl 1):S77-S112.

21. Halliwell B, Gutteridge JM. Role of free radicals and catalytic metal ions in human disease: an overview. Methods Enzymol 1990;186:185.

22. Rahman I. The role of oxidative stress in the pathogenesis of COPD implications for therapy. Treat Respir Med 2005;4(3):175-200.

23. Malhotra D, Thimmulappa R, Navas-Acien A, Sandford A, Elliott M, Singh A, et al. Decline in NRF2-regulated antioxidants in chronic obstructive pulmonary disease lungs due to loss of its positive regulator, DJ-1. Am J Respir Crit Care Med 2008;178(6):592-604.

24. Lacoma A, Prat C, Andreo F, Domínguez J. Biomarkers in the management of COPD. Eur Respir Rev 2009;18(112):96-104

25. Kim V, Rogers TJ, Criner GJ. New concepts in the pathobiology of chronic obstructive pulmonary disease. Proc Am Thorac Soc 2008; 5(4):478-485.

26. Dickens JA, Miller BE, Edwards LD, Silverman EK, Lomas DA, Tal-Singer R. COPD association and repeatability of blood biomarkers in the ECLIPSE cohort. Respir Res 2011;12:146.

27. Dahl M. Biomarkers for chronic obstructive pulmonary disease: surfactant protein D and C-reactive protein. Am J Respir Crit Care Med 2008;177(11):1177-1178.

28. Turino GM. COPD and biomarkers: the search goes on. Thorax 2008;63(12):1032-1034.

29. Dahl M, Nordestgaard BG. Markers of early disease and prognosis in COPD. Int J Chron Obstruct Pulmon Dis 2009;4:157-167.

30. Miller MR, Hankinson J, Brusasco V, Burgos F, Casaburi R, Coates A, et al. Standardisation of spirometry. Eur Respir J 2005;26(2):319-338.

31. Global Initiative for Chronic Obstructive Lung Disease. Global strategy for the diagnosis, management, and prevention of chronic obstructive 


\section{Diagnostic Utility of Biomarkers IN COPD}

pulmonary disease. Updated 2010. http://www.goldcopd.org/uploads/ users/files/GOLDReport_April112011.pdf. Accessed October 24, 2014.

32. Jindal SK, Malik SK. Smoking index-a measure to quantify cumulative smoking exposure. Lung India 1988;6(4):195-196.

33. Somani BL, Ambade V. A kinetic method amenable to automation for ceruloplasmin estimation with inexpensive and stable reagents. Clin Biochem 2007;40(8):571-574.

34. Qaseem A, Wilt TJ, Weinberger SE, Hanania NA, Criner G, van der Molen T, et al. Diagnosis and management of stable chronic obstructive pulmonary disease: a clinical practice guideline update from the American College of Physicians, American College of Chest Physicians, American Thoracic Society, and European Respiratory Society. Ann Intern Med 2011;155(3):179-191.

35. Lock-Johansson S, Vestbo J, Sorensen G. Surfactant protein D, Club cell protein 16, pulmonary and activation-regulated chemokine, Creactive protein, and fibrinogen biomarker variation in chronic obstructive lung disease. Respir Res 2014;15(1):147.

36. Bowler RP. Surfactant protein D as a biomarker for chronic obstructive pulmonary disease. COPD 2012;9(6):651-653.

37. Sin DD, Pahlavan PS, Man SF. Surfactant protein D: a lung specific biomarker in COPD? Ther Adv Respir Dis 2008;2(2):65-74.

38. Gao F, Koenitzer JR, Tobolewski JM, Jiang D, Liang J, Noble PW, Oury TD. Extracellular superoxide dismutase inhibits inflammation by preventing oxidative fragmentation of hyaluronan. J Biol Chem 2008;283(10):6058-6066.

39. Kliment CR, Tobolewski JM, Manni ML, Tan RJ, Enghild J, Oury TD. Extracellular superoxide dismutase protects against matrix degradation of heparan sulfate in the lung. Antioxid Redox Signal 2008; 10(2):261-268.

40. Petersen SV, Oury TD, Ostergaard L, Valnickova Z, Wegrzyn J, Thøgersen IB, et al. Extracellular SOD binds to type I collagen and protects against oxidative fragmentation. J Biol Chem 2004;279(14): 13705-13710.

41. Fattman CL, Tan RJ, Tobolewski JM, Oury TD. Increased sensitivity to asbestos-induced lung injury in mice lacking extracellular superoxide dismutase. Free Radic Biol Med 2006;40(4):601-607.

42. Folz RJ, Crapo JD. Extracellular superoxide dismutase (SOD3). Tissue specific expression, genomic characterization, and computerassisted sequence analysis of the human EC SOD gene. Genomics 1994;22(1):162-171.

43. Ahmed MN, Suliman HB, Folz RJ, Nozik-Grayck E, Golson ML, Mason SN, Auten RL. Extracellular superoxide dismutase protects lung development in hyperoxia-exposed newborn mice. Am J Respir Crit Care Med 2003;167(3):400-405.

44. Auten RL, O'Reilly MA, Oury TD, Nozik-Grayck E, Whorton MH. Transgenic EC superoxide dismutase protects postnatal alveolar epithelial proliferation and development during hyperoxia. Am J Physiol Lung Cell Mol Physiol 2006;290(1):L32-L40.

45. Ghio AJ, Suliman HB, Carter JD, Abushamaa AM, Folz RJ. Overexpression of extracellular superoxide dismutase decreases lung injury after exposure to oil fly ash. Am J Physiol Lung Cell Mol Physiol 2002;283(1):L211-L218.

46. Tan RJ, Fattman CL, Watkins SC, Oury TD. Redistribution of pulmonary EC-SOD after exposure to asbestos. J Appl Physiol 2004; 97(5):2006-2013.

47. Oury TD, Chang LY, Marklund SL, Day BJ, Crapo JD. Immunocytochemical localization of extracellular superoxide dismutase in human lung. Lab Invest 1994;70(6):889-898.

48. Oury TD, Day BJ, Crapo JD. Extracellular superoxide dismutase in vessels and airways of humans and baboons. Free Radic Biol Med 1996;20(7):957-965.

49. Yen CC, Lai YW, Chen HL, Lai CW, Lin CY, Chen W, et al. Aerosolized human extracellular superoxide dismutase prevents hyperoxia-induced lung injury. PLoS ONE 2011;6(10):e26870.
50. Zeng M, Li Y, Jiang Y, Lu G, Huang X, Guan K. Local and systemic oxidative stress status in COPD patients. Can Respir J 2013;20(1): $35-41$.

51. Gavali Y, Deore D, Surwase SP, Zingade U. Study of the serum superoxide dismutase levels in smoking and non-smoking patients with COPD. Int J Recent Trends Sci Tech 2013;5(3):121-126.

52. Tavilani H, Nadi E, Karimi J, Goodarzi MT. Oxidative stress in COPD patients, smokers and non-smokers. Respir Care 2012;57(12): 2090-2094.

53. Daga MK, Chhabra R, Sharma B, Mishra TK. Effects of exogenous vitamin $\mathrm{E}$ supplementation on levels of oxidants and antioxidants in COPD. J Biosci 2003;28(1):7-11.

54. Chakraborty I, Kunti S, Bandyopadhyay M, Dasgupta A, Chattopadhyay DG, Chakraborty S. Evaluation of serum zinc level and plasma SOD activity in senile cataract patients under oxidative stress. Indian J Clin Biochem 2007;22(2):109-113.

55. Kotur-Stevuljevic J, Spasic S, Jelic-Ivanovic Z, SpasojevicKalimanovska V, Stefanovic A, Vujovic A, et al. PON1 status is influenced by oxidative stress and inflammation in coronary heart disease patients. Clin Biochem 2008;41(13):1067-1073.

56. Comhair SA, Lewis MJ, Bhathena PR, Hammel JP, Erzurum SC. Increased glutathione and glutathione peroxidase in lungs of individuals with chronic beryllium disease. Am J Respir Crit Care Med 1999;159(6):1824-1829.

57. Kakkar P, Das B, Viswanathan PN. A modified spectrophotometric assay of superoxide dismutase. Indian J Biochem Biophys 1984; 21(2):130-132.

58. Matés JM. Effects of antioxidant enzymes in the molecular control of reactive oxygen species toxicology. Toxicology 2000;153(1-3):83104.

59. Valko M, Rhodes CJ, Moncol J, Izakovic M, Mazur M. Free radicals, metals and antioxidants in oxidative stress-induced cancer. Chem Biol Interact 2006;160(1):1-40.

60. Baud O, Greene AE, Li J, Wang H, Volpe JJ, Rosenberg PA. Glutathione peroxidase-catalase cooperativity is required for resistance to hydrogen peroxide by mature rat oligodendrocytes. J Neurosci 2004;24(7):1531-1540.

61. Nadeem A, Raj HG, Chhabra SK. Increased oxidative stress and altered levels of antioxidants in chronic obstructive pulmonary disease. Inflammation 2005;29(1):23-32.

62. Blum J, Fridovich I. Inactivation of glutathione peroxidase by superoxide radical. Arch Biochem Biophys 1985;240(2):500-508.

63. Alegría A, Barberá R, Clemente G, Farré R, García MJ, Lagarda MJ. Selenium and glutathione peroxidase reference values in whole blood and plasma of a reference population living in Valencia, Spain. J Trace Elem Med Biol 1996;10(4):223-228.

64. Paglia DE, Valentine WN. Studies on the quantitative and qualitative characterization of erythrocyte glutathione peroxidase. J Lab Clin Med 1967;70(1):158-169.

65. Hackett NR, Heguy A, Harvey BG, O'Connor TP, Luettich K, Flieder DB, et al. Variability of antioxidant-related gene expression in the airway epithelium of cigarette smokers. Am J Respir Cell Mol Biol 2003;29(3):331-343.

66. Osaki S, Johnson DA, Frieden E. The possible significance of the ferrous oxidase activity of ceruloplasmin in normal human serum. J Biol Chem 1966;241(12):2746-2751.

67. Curzon G. Some properties of coupled iron ceruloplasmin oxidation systems. Biochem J 1961;79:656-663.

68. Al-Timimi DJ, Dormandy TL. The inhibition of lipid autoxidation by human caeruloplasmin. Biochem J 1977;168(2):283-288.

69. Taylor JC, Madison R, Wong E, Mittman C. Do ceruloplasmin and elastase inhibition abnormalities influence the pathogenesis of COPD. Chest 1984;85(6 Suppl):45S. 


\section{Diagnostic Utility of Biomarkers IN COPD}

70. Verrills NM, Irwin JA, He XY, Wood LG, Powell H, Simpson JL, et al. Identification of novel diagnostic biomarkers for asthma and chronic obstructive pulmonary disease. Am J Respir Crit Care Med 2011;183(12):1633-1643.

71. Pedersen JZ, Franck C. Increased serum levels of ceruloplasmin in severe chronic airflow obstruction. Eur J Respir Dis 1987;70(3):140144.

72. de Torres JP, Cordoba-Lanus E, López-Aguilar C, Muros de Fuentes M, Montejo de Garcini A, Aguirre-Jaime A, et al. C-reactive protein levels and clinically important predictive outcomes in stable COPD patients. Eur Respir J 2006;27(5):902-907.

73. Dahl M, Vestbo J, Lange P, Bojesen SE, Tybjaerg-Hansen A, Nordestgaard BG. C-reactive protein as a predictor of prognosis in COPD. Am J Respir Crit Care Med 2007;175(3):250-255.

74. Akbulut HH, Ozden M, Deveci F, Muz MH. IL-6 and IL-8 levels in patients with acute exacerbation of chronic obstructive pulmonary disease. J Clin Diagn Res 2009;3(1):1285-1288.

75. van Durme YM, Verhamme KM, Aarnoudse AJ, Van Pottelberge GR, Hofman A, Witteman JC, et al. C-reactive protein levels, haplotypes, and the risk of incident chronic obstructive pulmonary disease. Am J Respir Crit Care Med 2009;179(5):375-382.

76. Deng ZC, Zhao P, Cao C, Sun SF, Zhao F, Lu CY, Ma HY. C-reactive protein as a prognostic marker in chronic obstructive pulmonary disease. Exp Ther Med 2014;7(2):443-446.

77. Mori K, Kurihara N, Hayashida S, Tanaka M, Ikeda K. The intrauterine expression of surfactant protein $\mathrm{D}$ in the terminal airways of human fetuses compared with surfactant protein A. Eur J Pediatr 2002;161(8):431-434.

78. Janssen R, Sato H, Grutters JC, Bernard A, van Velzen-Blad H, du Bois RM, van den Bosch JM. Study of Clara cell 16, KL-6, and surfactant protein-D in serum as disease markers in pulmonary sarcoidosis. Chest 2003;124(6):2119-2125.

79. Lomas DA, Silverman EK, Edwards LD, Locantore NW, Miller BE, Horstman DH, Tal-Singer R. Serum surfactant protein D is steroid sensitive and associated with exacerbations of COPD. Eur Respir J 2009;34(1):95-102.

80. Zaky DS, Naiem M, Eid HA, Adawy ZR, Abd-Elraheem SE, Mohamed ZA. Circulating surfactant protein-D as a biomarker of severity in stable chronic obstructive pulmonary diseases. Egypt J Chest Dis Tuberc 2014;63(3):553-559.

81. Liu W, Ju CR, Chen RC, Liu ZG. Role of serum and induced sputum surfactant protein $\mathrm{D}$ in predicting the response to treatment in chronic obstructive pulmonary disease. Exp Ther Med 2014;8(4): 1313-1317.

82. Sin DD, Leung R, Gan WQ, Man SP. Circulating surfactant protein $\mathrm{D}$ as a potential lung-specific biomarker of health outcomes in COPD: a pilot study. BMC Pulm Med 2007;7:135.

83. Bridges JP, Davis HW, Damodarasamy M, Kuroki Y, Howles G, Hui DY, McCormack FX. Pulmonary surfactant proteins A and D are potent endogenous inhibitors of lipid peroxidation and oxidative cellular injury. J Biol Chem 2000;275(49):38848-38855.

This article is approved for Continuing Respiratory Care Education credit. For information and to obtain your CRCE

(free to AARC members) visit www.rcjournal.com

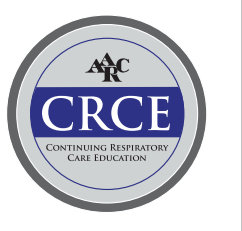

